https://jurnal.unigal.ac.id/index.php/jall/index

JALL (Journal of Applied Linguistics and Literacy), ISSN 2598-8530, September, Vol. 4 No. 2, 2020

\begin{tabular}{|ccc|}
\hline Received & Accepted & Published \\
\hline August 2020 & September 2020 & September 2020 \\
\hline
\end{tabular}

\title{
SCIENTIFIC APPROACH IN EFL YOUNG ADOLESCENTS TO PROMOTE HIGHER ORDER THINKING SKILLS: TEACHER'S STRATEGY, BENEFITS, AND CHALLENGES
}

\author{
Sri Setyarini \\ setyarini.english@upi.edu \\ English Education Department, Universitas Pendidikan Indonesia
}

\begin{abstract}
Higher Order Thinking as one of the main agendas in the Curriculum 2013 introduces several learning approaches - one of which is scientific approach. However, so far, the majority of English teachers in Indonesia still face some challenges due to their insufficient knowledge and experience in implementing this approach. This paper presents a research report on strategies of promoting higher order thinking skills (HOTS) in EFL young adolescents' classroom through scientific approach. It aimed to investigate how HOTS was promoted in the EFL classroom, identify benefits gained by the teacher and the students from the implemented approach, and find out teacher's challenges and solutions from the teaching practice. This study employed a case study involving a class of seventh grade students as research participants. To collect data, three instruments were used such as classroom observation, interview with the teacher and the students, and document analysis. The findings revealed that scientific approach with its components (observing, questioning, associating, exploring, and communicating) may promote students' HOTS as seen from their enthusiasm and active participation in the classroom. The students also focused more on showing ideas, arguments, and views toward the questions from other groups as proved by their statements in the interview claiming that they were trained to do analysis, evaluation, and creation through learning activities. Meanwhile, the teacher stated that her challenges in teaching dealt with her limited experience and knowledge to implement this approach. To overcome them, she committed to join professional development programs and improve her linguistic skills.
\end{abstract}

Keywords: EFL Classroom, Higher Order Thinking Skills, Scientific Approach, The Curriculum 2013, Young Adolescents 


\section{INTRODUCTION}

In the last five years, the Indonesian government has issued the new updated 2013 Curriculum through the Minister of Education and Culture with four agendas, including character education, literacy, 4C (communicative, creative, critical, and collaborative) and higher order thinking skills. These agendas promote the $21^{\text {st }}$ century learning objectives which require students to have both soft and hard skills in global competition. Nevertheless, the facts revealed that the implementation of critical thinking-based classrooms so far have not been promoted optimally due to the teacher's understanding toward the urgency of higher order thinking skills in the classroom. A study conducted by Setyarini et al. (2018) found several challenges faced by the teachers in implementing higher order thinking skills in language learning because they assumed that these skills were only applicable in science subjects. Besides, the findings of the study have highlighted that the teachers had inadequate linguistic skills to be inflexible to teach the students and develop classroom language and materials which encouraged the students' higher order thinking skills. Although they realized that higher order thinking skills stimulated them to be more critical and more wellprepared before teaching, but the teachers claimed that it demanded complex process of teaching and more time to prepare the materials (Setyarini et al., 2018). Another finding from Setyarini (2018) also showed that the assessments have not been associated with the principles of higher order thinking skills even though the teachers admitted that they have conducted the HOTS-based classrooms.

This is also supported by Abosalem (2016) who claimed that the majority of the teachers were still in trouble to make critical questions for the assessment, especially in the form of open-ended questions. It was due to the nature of the assessment which intends to achieve a range of purposes by using different methods and techniques. Consequently, the teacher made assessment overly emphasized on memory for facts and gave more weight to lower levels. Another factor influencing the inability of the teacher in designing higher order thinkingbased assessment was the lack of the training joined by the teachers. As stated by Boyd (2008) most of the teachers are not trained in to construct this type of questions or they are reluctant to use a new testing approach due to the time needed to design such tests. On the other side, the government had not been disseminated 
the types of questions and procedures in assessing Indonesian students' higher order thinking skills optimally to all levels of education. It led to the misconception among the teachers claiming that higher order thinking skills assessment was similar with the difficult questions (Setyarini et al., 2018).

Instead of looking at the implementation progress of higher order thinking skills from the teacher's voices, it also needs to consider the students' factors as the target receiver of learning process. The Indonesian Ministry of Education and Cultures as explained by Widodo and Kadarwati (2013) underlined that the students were accustomed to use lower order thinking skills in learning by recalling facts and understanding information. It was in contrast with the required competencies formulated by the government emphasizing the development of students' three domains (cognitive, affective, and psychomotor).

To escape from the lower order thinking-based learning, scientific approach with five principles enables students to observe, question, associate, explore, and communicate the information they gained from the learning activity. These principles also empower them to possess not only the cognitive skills but also affective and psychomotor ones (Anderson \& Krathwohl, 2001). By doing so, learning outputs will accommodate students to be independent learners who have strong competitive struggles in facing global era.

Some studies have been conducted focusing on the implementation of scientific approach in teaching English as a foreign language. They concerned on the strategy in teaching English without exposing HOTS principles in classroom actitivity (Nugraha \& Suherdi, 2017; Zaim, 2017). As a result, the students have not been exposed on the strategies of how to present their ideas and arguments either in a group or classroom discussion because th teacher did not promote their analytical, evaluative, and creative skills (Setyarini et al., 2018).

The findings of those studies highlighted that some EFL teachers in Indonesia were unable to met the regulation issued by the Minister of Education and Culture about the process of learning in the Curriculum 2013 to provide opportunities for students to be able to develop any learning patter that occurs inside the two ways interaction between teachers and students. The teachers played dominant roles in the classroom who positioned students as the passive 
recipients of the materials. To help the teachers understand better of how to implement critical thinking-based classroom, Shofwan (2017) mentioned that in the Curriculum 2013, learning activities should apply scientific approach which requires students to think scientifically and critically as well as develops the sense of inquiry.

Scientific apporach is basically developed as the improvement of the previous implemented approach (Genre-based Approach) and it puts more emphasis on the active construction of knowledge of the students. According to Agustien (2014), the target domains of scientific approach are science skills whereas genre-based approach focuses on communication skills. The definition of scientific approach accroding to Longman (2014) in Zaim (2017) is a process of finding out information in scientifically involving testing the ideas by performing experiments and making decisions based on the analysis results. It refers to the idea that scientific approach is a body of techniques for investigating phenomena, acquiring new knowledge, correcting and integrating previous knowledge. The main feature of scientific approach is allowing the teachers to improve the process of learning by breaking the process down into steps or stages which contains detailed instructions for doing learning (Tang et al., 2009). This feature was then adopted as the basis for implementing the 2013 curriculum.

To promote students' critical and scientific thinking, Setyarini (2016) believed that English language teaching can be done in accordingly with some strategies of Higher Order Thinking-based activities, including giving open-ended questions, teaching from abstract to concrete, roleplaying, and gesturing. The study also revealed that students' cognitive levels particularly analysing and evaluating levels could improve students' speaking skills through those strategies as seen from their opinions, arguments, and judgements. Moreover, Zohar and Dori (2003) asserted that higher order thinking skils helps students in practicing literacy. Students will be able to gain more vocabulary, understand grammar, and get meaning of discourse in a holistic manner.

Although the term of scientific approach and higher order thinking skills are familiar for some teachers, it seems very new for English teachers (Setyarini, 2018). This is due to some methods that commonly employed by the EFL teachers 
which are not related with the scientific terms and procedures, such as grammar translation, audiolingual, communicative language teaching, and natural approach (Richard \& Rodgers, 2001 in Shofwan, 2017). As an impact, the teachers were still confused and unsrue in implementing the scientific approach for teaching English to the students and the formulated learning objectives could be achieved optimally. Therefore, this paper presents a research report on strategies of promoting higher order thinking skills in EFL young adolescents through scientific approach and identify the benefits gained by the teacher and the students as well as find out teacher's challenges and solutions from the teaching practice.

\section{METHOD}

This study applied a qualitative method with case study as a research design due to several reasons. First, case study seeks to provide a holistic description of complex phenomena (Hancock \& Algozzine, 2017) as this study aims to analyse, describe, and interpret data in the form of teacher's strategies in implementing scientific approach to promote students' higher order thinking skills. The main objective of such inquiry-based study is investigating inadequately presented phenomenon that cannot be quantified since it needs a direct description from the experienced respondents of such phenomenon. Therefore, in this context, the data were collected from an English teacher as respondent who has direct experience in implementing scientific approach in the classroom.

This qualitative study deployed the researcher as the main instrument of the study by collecting the data themselves through observing, interviewing, and analysing related documents. Moreover, since this study analysed how the teacher used some strategies in scientific approach to promote students' higher order thinking skills, then this study could be considered as a case study design (Creswell, 2009). This study also limited the case to a specific participant in which the participating teacher and the students were considered to have experiences in learning through scientific approach. 
In addition, one class from one selected school in Bandung was selected as the research participants of this study. During the process of collecting data, three research instruments were occupied by the researcher, such as classroom observation, interview with the students and the teacher, and document analysis. Regarding the types of the classroom observation, Cowie (2009) mentioned two types of observation that can be done in a case study, namely participant observation and field notes. Participant observation requires the researcher to take part in the daily activities of the individual being observed, while the field notes are taken on the spot or as soon as possible (Cowie, 2009).

This study was also used a semi-structred interview to make the students and the teacher comfortable in answering questions without any worry or making them hiding something. As stated by Richards (2009), a semi-structured interview is a kind of interiew which is more informal than the structured one and ease both the researcher and the participants in collecting data. It also inline with Rustandi et al. (2020) that semi-structured interview is relevant to this topic. The interviews were done in two languages (Bahasa Indonesia and English) and they were free to choose one of them if they wanted to.

Regarding document analysis, Bowen (2009) described that document analysis is a technique used to categorize, investgate, interpret, and identify the limitation of physical sources, most commonly written documents whethere in the private or public domain. Regarding this study, some documents were analysed to obtained the data covering lesson plans made by the teacher, students' written works, and some teaching media employed by the teacher. All of these documents helped the researchers by providing some information related to the implementation of this learning approach.

After the data from the three instruments have been gained, the data analysis was conducted to answer the research questions of this study. Qualitative descriptive analysis was employed as the main approach of this study since it focused on how higher order thinking skills were promoted in EFL classroom through scientific approach which required detail description and interpretation about the teacher and students' experience in the implementation. 
The process of analysing the data was done both under and after the implementation of the learning approach. It is in line with the statement of Hancock and Algozzine (2017) who claimed that on going data analysis is essential to ensure that the data are clean and free from incompleteness and discover additional themes that may be needed. Regarding this, the data gained from classroom observations were analysed duing the process of the study while the data from the document analysis and interviews were interpreted after the completion of the study.

\section{FINDINGS AND DISCUSSION}

\section{RESEARCH FINDINGS}

\section{EFL Teacher's Strategies in Promoting Students' Higher Order Thinking Skills through Scientific Approach}

The findings of this study show that the teacher-participant followed the stages in implementing the scientific approach as suggested by the Minister of Education and Culture including observing, questioning, experimenting, associating, and communicating. However, each of those stages were delivered through some strategies promoting the students' higher order thinking skills such as brainstorming, giving open-ended questions, providing abstract to concrete concepts, mind-mapping, and role playing.

The learning process lasted for about 90 minutes to implement the approach by teaching descriptive text as a genre. The topic introduced by the teacher was My Lovely Stuffs aiming at exposing the students to contextual objects which were used later in their text. To be brief, the teacher divided a set of learning process into three sections, namely opening, main activity, and closing in which every section were employed certain strategies.

The first section is opening section where the teacher implemented observing stages to provide a wide opportunity for the students to conduct a critical observation. To help the students run this stage, the teacher selected some explicit instructions including determining the objects to be observed, explaining the purposes, designing the observation procedures, limiting the objects, asking the students to conduct the observation, reporting the results of the observation, 
and comprehending the results. Determining the objects to be observed was started by the teacher through brainstorming strategy that required them to think about their favourite objects or stuff. The teacher firstly showed a bedroom with furnished stuffs and gave some questions. The students were free to answer the teacher by pointing one of the objects they observed from the pictures. The next question was asking about the students' opinions toward the objects by saying: What do you think of this stuff?. From this very beginning activity, the teacher already got some insights what critical responses the students made. In this session, the teacher drew some cycles to put vocabulary and idea from the students. It was intended to show the students a variety of words and ideas so that they could identify well characteristics of the stuffs. After getting the vocabulary and opinions web, the teacher divided the class into some groups of five students. Each group gained a piece of pictures and they were requested to identify the stuffs and comment on the characteristics of the stuff. By doing so, the teacher aimed at extending the students critical understanding towards the pictures they identified and stimulated the students to promote their HOTS through comparing, contrasting, evaluating, deciding, and taking action as they chose which stuff was the most favourite and functional for them.

To help groups worked effectively, the teacher provided some guided questions, such as: What is the things that you love most? Why do you like it? How about those objects were gone from you?. Those questions were exposed to construct students' knowledge about the objects to be discussed. The teacher admitted that employing students' prior knowledge in learning through the students' context enabled them to think more critically because they were familiar with the objects that they liked most. The results of the classroom observation showed that the students looked enthusiastic about giving their answer and explained in detail their favourite stuffs as seen in the following table:

Table 1 Teacher's Questions and Students' Answers in Brainstorming Activity

\begin{tabular}{|c|c|ll|}
\hline No & Teacher's Questions & \multicolumn{1}{c|}{ Students' Answers } \\
\hline 1 & $\begin{array}{c}\text { What is the things that } \\
\text { you love most? }\end{array}$ & $\begin{array}{l}\text { ・ } \\
\text { Barbie doll } \\
\text { - Story books }\end{array}$ \\
\hline 2 & School bag \\
\hline
\end{tabular}




\begin{tabular}{|c|c|c|}
\hline & & $\begin{array}{l}\text { - I got this book from my cousing who is very } \\
\text { nice to me } \\
\text { - This school bag is my birthday gift and it helps } \\
\text { me bring some books everyday }\end{array}$ \\
\hline 3 & $\begin{array}{l}\text { How about those objects } \\
\text { were gone from you? }\end{array}$ & $\begin{array}{l}\text { - I will be so sad because I will have nothing to } \\
\text { stay with me } \\
\text { - I will ask for apology to my cousin } \\
\text { - I will wait for the next birthday, just in case I } \\
\text { will have another one. }\end{array}$ \\
\hline
\end{tabular}

To enable the teacher identified the students' HOTS, she made checklist involving three skills, namely analysing, evaluating, and creating from the group oral performance. After listening to the students' oral presentation, the teacher moved on to the objects in the classroom that they liked most. She also explained to the students that it aimed to construct their knowledge toward descriptive text through direct objects that were close to them. Moreover, the students were required to conduct an observation to the selected object and make notes about its features by giving guidance as can be seen in the following table:

Table 2 Observation Guide Given to the Students

\begin{tabular}{|l|l|l|l|l|l|l|}
\hline No & Names of Objects & Size & Shape & Function & Quality & Notes \\
\hline & & & & & & \\
\hline & & & & & & \\
\hline & & & & & & \\
\hline
\end{tabular}

Providing the observation guide presented above, it was found helpful because the students could focus their observation and find vocabulary as they needed to write their descriptive text.

Mind mapping was another strategy done after brainstorming. It was executed through working in groups. The results of observation done by the students were identified carefully and each word they collected was then categorized based on the part of speech of the vocabulary. Mind-mapping was 
done in different styles. Some groups made it in the form of table, while some others created a tree diagram and as can be seen in the following:

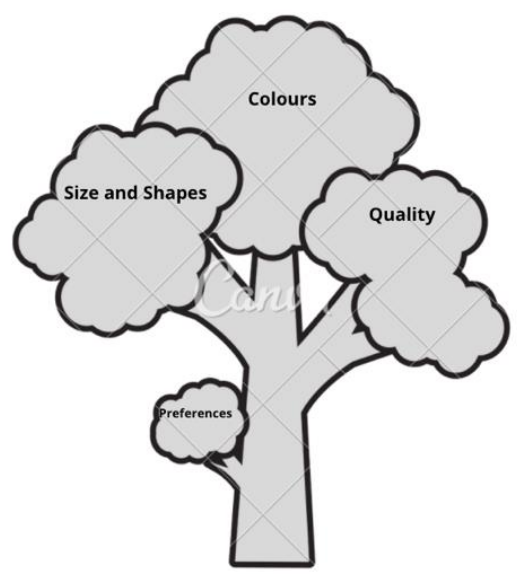

Figure 1. 1 Tree Diagram Made by the Students

Before presenting group discussion results in mind-mapping, the teacher gave some open-ended questions. It purposes to bring the students explore their opinion in describing the stuff or objects they observed. Moreover, these questions also promoted their HOTS because they should described the stuff through analysing and evaluating that can be seen from their statements during the presentation as in the following table:

Table 3 Students' Statements in the Presentation

\begin{tabular}{|l|l|}
\hline \multicolumn{1}{|c|}{ Presenter's Statement } & \multicolumn{1}{c|}{ Audience Responses } \\
\hline $\begin{array}{l}\text { This is the stuff we like most in our } \\
\text { classroom }\end{array}$ & $\begin{array}{l}\text { Yes it is good but we do not like it. } \\
\text { Do you know why? }\end{array}$ \\
\hline It is oval and big & \\
\hline The colour is amazing & \\
\hline Do you like it? & \\
\hline
\end{tabular}

The second section was the main activity in which the teacher employed experimenting and associating. These two strategies were filled with plus minus interesting, making abstract to concrete, and focused-group discussions. Plus minus interesting was done to investigate the students' HOTS in describing the stuff and gave their comments on it. To make the class activity effective, the 
teacher provided a table of plus minus interesting which can be seen from the above table:

Table 4 Plus Minus Interesting done in the Classroom

\begin{tabular}{|c|c|c|c|c|c|}
\hline \multicolumn{6}{|c|}{ MY FAVOURITE STUFFS } \\
\hline \multirow[b]{2}{*}{ No } & \multirow[b]{2}{*}{$\begin{array}{l}\text { Name of } \\
\text { Stuffs }\end{array}$} & \multicolumn{3}{|c|}{ Rating } & \multirow[b]{2}{*}{ Descriptions/ Reasons } \\
\hline & & $\begin{array}{l}\text { We like it } \\
\text { very } \\
\text { much }\end{array}$ & $\begin{array}{l}\text { We like } \\
\text { it, but } \\
\text { not very } \\
\text { much }\end{array}$ & $\begin{array}{l}\text { We do } \\
\text { not like it }\end{array}$ & \\
\hline 1 & White board & $\mathrm{V}$ & & & $\begin{array}{l}\text { Large, Square, } \\
\text { White, Glean, } \\
\text { Sketching. }\end{array}$ \\
\hline 2 & Calendar & & $\mathrm{V}$ & & $\begin{array}{l}\text { Nice pictures, colourful, } \\
\text { big, important to check my } \\
\text { birthday }\end{array}$ \\
\hline 3 & Trash bin & & & $\mathrm{V}$ & $\begin{array}{l}\text { Too small, dirty, smelly, } \\
\text { messy. }\end{array}$ \\
\hline & $\begin{array}{l}\text { What we nee } \\
\text { Keep mainta }\end{array}$ & $\begin{array}{l}\text { to do is: } \\
\text { ing the stu }\end{array}$ & vell. & & \\
\hline
\end{tabular}

Making abstract to concrete was another strategy given during the learning process. This task was a follow up activity from the previous one (PMI). From the table made by each group, they were asked to put their ideas clearly in their descriptive writing, particularly to what they exactly thought about the stuff and wanted to put their idea in their writing. In other words, it was a real action what the students had in their mind and put them the real descriptions.

Focused-group discussion was another strategy done in learning process. The teacher used it to accommodate the results of observation, discussion, presentation into the final group discussions. This task offered the students to demonstrate their arguments, debates, reasons by convincing to the other groups 
based on their perspectives. In this activity, the teacher had a role as mediator and facilitator which required her to show fairness and appraisal toward the students' performances and ideas. HOTS seemed to be well clearly identified during this activity.

The last sessions dealing with the stage of scientific approach was communicating executed through evaluating and reflecting. Evaluating was done by the students in group in which they made summary including the points of their learning in the form of descriptive text. Evaluative opinion was gained from the other groups' and the teacher comments. By doing so, the students believed their descriptive writing revealed clear and opiniated descriptions. To complete their task, the students reflected their observation results, group discussions, and suggestions from the teacher which were supported by their prior knowledge and experience.

\section{The Benefits Gained by the Teacher and the Students}

Based on the data gained from the interview, it was found that the teacher and the students gained benefits from scientific approach. The teacher realised that scientific approach accommodate the students explored and experienced in promoting HOTS. Being analytical, evaluative, and creative were exposed through some components of SA that were split and filled with different learning strategies. By doing so, the teacher claimed that this learning model helped her in asking the students to be engaged. Furthermore, the teacher also found it more interesting class because the students explored their activity through several different strategies.

For the students, this learning model gave some benefits such as creating joyful learning atmosphere, offering flexibility in learning, and building students' confidence in learning. Creating joyful learning athmosphere occurred when the students learned new materials from the familiar contexts of the students and had discussions with their friends. The students mentioned that this kind of strategy felt like a story sharing with their friends that happened naturally. The following extract presents the student's opinion toward the pleasure they experienced in the classroom: 
"I love it when the teacher asked me to think about the objects around me. It feels like telling a story to my friend that we always do every day. I did not even realise that I was learning something new at that day"

(Interview with the student A)

The student's statement above is also supported by the teacher who believed about the positive impact of schemata to construct students' information. The teacher claimed that the students were coming from different backgrounds and experience that might be possible to be brought in the classroom as seen below:

"I do believe that my students are coming from different backgrounds and have different experience. It is a good idea to bring their experiences into the classroom contexts, so they will be easier to construct new information as they are familiar about it".

(Interview with the teacher)

Moreover, the students in the interview also claimed that they were more flexible in doing some learning activities. They were not be afraid in making any mistakes especially related to grammatical errors both in speaking and writing. It was due to the principles of higher order thinking skills that required students to think more than recalling and understanding facts so they would have more opportunity to further explore the ideas. The following extract indicates the student's statement regarding the flexibility in learning:

"I am more comfortable in learning because I do not need to be worry in making mistakes while speaking and writing. So, I could convey my thoughts without any doubt in class".

(Interview with the student C)

Since the students were flexible and very sure in delivering their ideas through scientific approach, the students were also admitted that this learning made them more confident about their achievement in learning a foreign language. They claimed that previously, the students only passed through a riggid learning process where they only answered some closed-questions either in the form of multiple-choices or essay. The students further mentioned that the teacher frequently asked them to recall certain facts rather than allowed them to think from other perspectives. Consequently, the students became more confident after the 
completion of this study. This is clearly seen from the result of the interview with the students presented below:

"I prefer to learn through this way. I could express any idea that comes up into my mind and I am more confident than before"

(Interview with the student D)

\section{Challenges Faced by the Teacher and the Solutions to Overcome Them}

Apart from the benefits gained by the students from the learning process, the teacher claimed that she faced some difficulties in promoting students higher order thinking skills through scientific approach, especially in developing an active learning atmosphere in the classroom. The teacher mentioned that building critical questions as stimulus to invite the students' responses was very difficult to conduct because she had no experience previously in teaching higher-order thinking-based classroom. The teacher in the interview admitted that promoting students' higher order thinking skills was believed as a complex process of teaching because she needed to prepare and think higher than usual to involve the students in learning process as seen in the following extract:

"I thought promoting higher order thinking skills of the students was very hard to do because I had to deal with complicated process of thinking, prepare more time to design the lesson plan and learning activities. This is my first time to teach higher-order thinking-based classroom",

(Interview with the teacher)

Moreover, the teacher also dealt with some grammatical errors in providing the questions since these questions should be immediately made adjusting with the students' responses. To avoid misunderstanding, in some cases, the teacher preferred to repeat the questions in Bahasa Indonesia for the purpose of clarity. The table below describes the grammatical errors made by the students gained from the classroom observation:

Teacher : OK. Now, please pick one object that most you like and said it to your friend why the reasons you like it.

Students $\quad:$........ (no response) 

kamu suka dan katakana ke teman kalian mengapa kalian menyukainya.

(Excerpt from the Classroom Observation)

Regarding the difficulties faced by the teacher in implementing scientific approach, the teacher applied some strategies to solve those problems. First, the teacher mentioned that it was important to determine the learning objectives and goals before conducting the learning process. She believed that it would be easier for her to create valuable critical questions that could extend the students' ideas and opinions. Besides, the teacher was supposed to modify or create original teaching materials that were able to accommodate the students' characteristics. The teacher usually simplified the language used in the textbooks or other sources that were able to accommodate the students' characteristics and thinking levels.

To familiarize the teacher with the concept of scientific approach and higher order thinking skills, the teacher admitted that she joined some professional development programs. These programs allowed her to share the experience in using scientific approach to other teacher and helped her to gain new insights from the professional teachers. Without joining professional development programs, the teacher asserted that she would not be able to implement this approach properly.

\section{RESEARCH DISCUSSION}

The implementation of higher order thinking skills to promote students' higher order thinking skills done by the teacher support the major concept of HOTS as suggested by King, Goodson, and Rohani (2012). Firstly, the teacher should understand that levels of thinking could not be unmeshed from the levels of learning since they involve interdependence, multiple components and levels. Second, whether or not thinking can be learned without subject matter content is only a theoretical point. In the real life, the students will learn content in both community and school experiences, no matter what theorist conclude, and the concepts and vocabulary they learn in the prior year will help them learn both higher order thinking skills and new content in the coming year. Third, higher 
order thinking skills and new content involves a variety of thinking processes applied to complex situations and having multiple variables. To effectively teach these skills, the teacher is suggested to bring students' schemata to the new materials.

The results of this study indicate that scientific approach was implemented through several essential stages such as observing, questioning, associating, experimenting, and communicating. These stages were done through sequential ways starting from observing stages as the simple stage to commonucating as the final stage in the closing phase. Generally, concerning on the implementation of scientific approach, the teacher realised the main objectives of promoting higher order thinking skills through some strategies, namely brainstorming, mind-mapping, showing pictures, open-ended questions, making abstract to concrete, plus minus interesting, focused-group discussion, making evaluative and reflective comments.

To achieve the learning objectives successfully, the teacher put emphasis on the contexts of the students to the new materials presented. As explained by King, Goodson, and Rohani (2012), contexts is a major concept that affect the level of someone's thinking because real-world situation provides many challenges for an individiual to think critically. Furthermore, the teacher also used open-ended questions in a whole learning process to allow the students explore their ideas from different perspectives.Concerning to the impact on cognitive skills, the students noted that scientific approach helped them to comprehend learning content given by the teacher including improving their comprehension about the descriptive texts as well as the behavioural aspects.

\section{CONCLUSION}

Based on the data analysis results, some points could be concluded. First, scientific approach was considered as a method that can promote the young adolescents' higher order thinking skills. The implementation of this approach also provided some benefits to the teacher and the students although some challenges were met during the implementation. To implement this approach, some components were splitted and filled with some learning strategies. Overall, 
all of those were groupped into three learning sections, namely opening, main activity, and closing.

In opening section, observing and questionning were executed with brainstorming, mind-mapping, showing pictures, and open-ended questions. These strategies were intended to stimulate the students critical opinions and make the students engaged in their learning. In this context, most of the students involved actively as can be seen from their enthusiasm and classroom participations either in a group discussion or classroom ones.

Finding new vocabulary relating to names of items surrounding, shape and colours, and quality of the stuffs they were going to describe was an evidence that the students had promoted their HOTS. In addition, through observing and questioning activity the students got opportunity and experience to be critical which were performed from their analytical and evaluative opinions.

Experimenting and associating as the other components of scientific approach were realised in the main learning stage. These components were done through making abstract to concrete, plus minus interesting, and focused group discussion. Making abstract to concrete was intended to train students put their imaginative ideas about their favourite or wanted stuffs in their descriptive writing. From this activity, the students were exposed to be able to promoted their HOTS because they could write their opinion based on their analytical and evaluative ones.

Moreover, to promote the students' critical thinking, the teacher introduced plus minus interesting strategy in focused-group discussion. It was aimed to get shared opinion amongst the members to enrich the idea before writing descriptive text. However, to run this activity, the teacher explained how the procedures in advance. Therefore, the students could apply this strategy well in group. Moreover, making abstract into concrete and plus minus interesting were simuteanously equiped to apply focused group discussions. Each group presented the results of the discussion in front of the class. It gave opportunity to the students to get new insights, ideas, suggestions from the other groups. It was good input to revise their descriptive writing to be better than before. 
The last session of scientific approach was communicating done through evaluating and reflecting tasks. The students were required to make evaluative comments given either in their oral or written ones. Their evaluative oral comments could be seen from their arguments, opinions, reasons in classroom discussions. Whereas, the written ones could be proved from their writing.

The results of data from the interview with the teacher and the students, it was investigated that both of the teacher and the students gained benefits from this approach. The teacher claimed that she found it helpful to arrange the learning activity more sequentially. She also recognized it more authentic in delivering the materials and doing the assessments. Students enthusiasm and active classroom participation encouraged her to teach more interestingly. In term of the benefits for the students, they found their classroom activities were joyful, flexible, and conducive. They met their classroom practice to offer good experience in using the language for communication, particularly during group discussion and classroom presentation. Besides they also stated that their learning offered some exposure on how to be critical through giving some ideas, comments, arguments, and reasons to describe the objects more detail even they were requested their prior knowledge and experience.

In spite of benefits of implementing scientific approach to promote the students' HOTS, the teacher also faced some challenges such as lack of teaching experience using scientific approach, insufficient linguistic knowledge, and time shortage. To overcome those challenges, the teacher comitted to keep implementing scientific approach by improving the materials, arranging more interesting learning activity, choosing the appropriate learning media, and assessment.

Moreover, the teacher also stated that she was required to join some professional developments programs which allowed her to discuss and share experience with other teachers who have implemented this approach. By doing so, she was optimistic to be able to implement scientific approach for teaching adolescents well. 


\section{REFERENCES}

Abosalem, Y. (2016). Assessment techniques and students' higher order thinking skills . International Journal of Secondary Education, 1-11.

Agustien, H. I. (2014). The 2013 curriculum: The paradigm, interpretation, and implementation. English Language Education Journal.

Anderson, L., \& Krathwohl, D. (2001). A taxonomy for learning, teaching, and assessing: A revision of Bloom's taxonomy of educational objectives . Boston: Pearson Education Group.

Bowen, G. (2009). Document analysis as a qualitative research method. Qualitative Research Journal, 29-40.

Boyd, B. (2008). Effects of state tests on classroom test items in mathematics . Journal of School Science and Mathematics , 251-261.

Cowie, N. (2009). Observation. In J. Heigham, \& R. Croker, Qualitative research in applied linguistics: A partial introduction (pp. 165-181). London: Palgrave Macmillan.

Creswell, J. (2009). Research design: qualitative, quantitative, and mixed method approaches. California: SAGE Publication.

Hancock, D., \& Algozzine, B. (2017). Doing case study research: A practical guide for beginning researchers. New York: Teachers College Press.

King, F., Goodson, L., \& Rohani , F. (2012). Higher order thinking skills: Definition, teaching strategies, and assessment. Florida: Educational Service Program.

Nugraha, I. S., \& Suherdi, D. (2017). Scientific approach: An English learningteaching (ELT) approach in the 2013 curriculum. Journal of English Education, 112-119.

Richards, K. (2009). Interviews. In J. Heigham, \& R. Croker, Qualitative research in applied linguistics: A practical introduction (pp. 182-199). London: Palgrave Macmillan.

Rustandi, A., Said, I., Carreon , J. R., \& Sanif , S. B. (2020). INTERCULTURAL COMMUNICATION SENSITIVITY IN GLOBAL ACADEMIC NETWORKING: EFL TEACHERS TRAINEES' PERCEPTIONS . JALL (Journal of Applied Linguistics and Literature), 1-12.

Setyarini, S. (2016). Higher order thinking (HOTS) in storytelling: An innovative learning model to improve speaking skill of grade seventh students in 
Bandung. The 4th Literary Studies Conference (pp. 196-198). Yogyakarta : English Letters Department, Universitas Sanata Dharma.

Setyarini, S., Muslim, A., Rukmini, D., Yuliasri, I., \& Mujianto, Y. (2018). Thinking critically while storytelling: Improving children's HOTS and English oral competence. Indonesian Journal of Applied Linguistics.

Shofwan, M. I. (2017). The use of scientific approach in teaching English as a foreign language in SMPN 1 Jakarta. Edulingua: Jurnal Linguistik Terapan dan Pendidikan Bahasa Inggris.

Tang, X., Coffey, J., Elby, A., \& Levin, D. (2009, July 22). The scientific method and scientific inquiry: Tension in teaching and learning. Wiley Periodicals, pp. 29-47.

Widodo, T., \& Kadarwati, S. (2013). Higher order thinking berbasis pemecahan masalah untuk meningkatkan hasil belajar berorientasi pembentukan karakter siswa. Cakrawala Pendidikan, 161-171.

Zaim, M. (2017). Implementing scientific approach to teach English at senior high school in Indonesia. Journal of Asian Social Science, 33-40.

Zohar, A., \& Dori, Y. (2003). Higher order thinking skills and low-achieving students: Are they mutually exclusive? . Journal of Learning Sciences, 145-181. 